\title{
Przestrzenny wymiar procesów transformacji przemysłu w województwie pomorskim
}

Zachodzące od ponad dwudziestu lat w Polsce procesy transformacji gospodarki, w tym transformacji przemysłu, należy rozpatrywać w kilku wymiarach. Po pierwsze, w wymiarze merytorycznym, w którym diagnozie i ocenie będą podlegać przyczyny, istota, mechanizm, formy i skutki przemian. Po drugie, w wymiarze czasowym, bowiem dla zaistnienia, przebiegu oraz skutków różnorodnych procesów transformacji gospodarki muszą zaistnieć korzystne okoliczności czasowe oraz właściwy zasób czasu - zwykle różny dla różnych procesów. Warto przy tym pamiętać, że ocena zachodzących przemian często zmienia się wraz ze zmianą horyzontu czasowego. Po trzecie, procesy transformacji gospodarki wypada rozpatrywać w wymiarze przestrzennym, gdyż ich przebieg i treść mają silne uwarunkowania lokalne i regionalne.

Wymiar przestrzenny analizy procesów transformacji gospodarczej, w tym transformacji przemysłu, najczęściej utożsamia się z miejscem, gdzie zachodzą zmiany. Jednak poprzez wymiar przestrzenny można nie tylko wskazać, gdzie (w jakim punkcie) zachodzą przemiany, czy też dokonać analizy w szerszym kontekście, tj. określić ośrodki, okręgi, regiony przemysłowe przodujące (lub też zapóźnione) w tych przemianach. Wymiar przestrzenny pozwala również etykietować niektóre rozwiązania, przy wcześniejszym przyjęciu określonych kryteriów. Do takich kryteriów można zaliczyć elastyczność przedsiębiorstw przemysłowych (Ziąber 2003).

Należy w tym miejscu dodać, że kreowanie elastyczności, obok osiagania efektywności i zapewnień jakościowych, jest podstawowym wymiarem ewolucyjnie kształtującego się paradygmatu zarządzania organizacjami, będąc jednocześnie narzędziem konkurowania (Krupski 2005, Volberda 1998).

Elastyczność funkcjonowania przedsiębiorstw, czyli zdolność do ciagłego zmieniania się, czy - jak metaforycznie ujmuje to G. Osbert-Pociecha (2009) - „tańczenie w turbulentnym otoczeniu" niesie w sobie wyraźnie wymiar przestrzenny, ponieważ jednym z atrybutów przyjmowanych elastycznych strategii działania jest przestrzeń (Krumme 1969; Walker 1975).

Ponadto w rozważaniach nad wymiarem przestrzennym elastyczności funkcjonowania przedsiębiorstw istotna jest definicja T. Stryjakiewicza (1999), który mówiąc o adaptacji przestrzennej, nazywa ją zespołem procesów przystosowawczych do zmian otoczenia, w tym innych aktorów gry rynkowej. W rzeczywistości definiuje on elastyczność zachowań przedsiębiorstw, odnosząc ją do uwarunkowań przestrzennych. 
Powyższe rozważania, jak również postawiony na ich podstawie problem badawczy dotyczący próby odpowiedzi na pytanie, jaki jest wpływ elastycznych strategii działania przedsiębiorstw przemysłowych, silnie determinowanych umiejscowieniem, na strukturę przestrzenną przemysłu województwa pomorskiego, stały się przyczynkiem do badań ankietowych.

Badania przeprowadzono na grupie 73 przedsiębiorstw z całego województwa pomorskiego, co stanowiło 3,47\% wszystkich przedsiębiorstw przemysłowych, spełniających wymagane warunki ${ }^{1}$. Ankietyzacja była realizowana w 2009 roku, lecz z przyczyn strategicznych badania dotyczyły działań podejmowanych w latach 2007-2008. Dobór przedsiębiorstw do badań miał charakter kwotowy. Zachowano przy tym zasadę proporcjonalności próby względem liczby przedsiębiorstw w każdym z subregionów województwa pomorskiego.

Głównym narzędziem ankietowym był kwestionariusz, dla którego inspiracją były prace Sushila (2001) oraz Osbert-Pociechy (2009), bowiem w badaniach wykorzystano podejście metaforyczne, nieco zmodyfikowane przez autora (tab. 1).

Tab. 1. Strategie adaptacji przestrzennej - ujęcie metaforyczne

\begin{tabular}{|l|l|l|l|}
\cline { 2 - 4 } \multicolumn{5}{c|}{} & \multicolumn{3}{|c|}{$\begin{array}{c}\text { Wybrane płaszczyzny } \\
\text { funkcjonowania przedsiębiorstwa }\end{array}$} \\
\cline { 2 - 5 } & Ludzie & Produkcja & Lokalizacja \\
\hline \multirow{5}{*}{ Elastyczne strategie adaptacji - podejście metaforyczne } & Bambus & Bambus & Bambus \\
\cline { 2 - 5 } & Kameleon & Kameleon & Kameleon \\
\cline { 2 - 5 } & Gepard & Gepard & Gepard \\
\cline { 2 - 5 } & Gitara & Gitara & Gitara \\
\cline { 2 - 5 } & Jaskółka & Jaskółka & Jaskółka \\
\cline { 2 - 5 } & Dziecko & Dziecko & Dziecko \\
\cline { 2 - 5 } & Wnuczek & Wnuczek & Wnuczek \\
\cline { 2 - 5 } & Matka & Matka & Matka \\
\cline { 2 - 5 } & Niebo & Niebo & Niebo \\
\hline
\end{tabular}

Źródło: Opracowanie własne na podstawie prac Sushila (2001) oraz Osbert-Pociechy (2009)

Istota badania polegała na wskazaniu przez osobę reprezentująca przedsiębiorstwo takich strategii, które najbardziej oddawały zachowanie przedsiębiorstwa w latach 2007 i 2008 w trzech płaszczyznach: ludzie, produkcja i lokalizacja.

Przyjęcie metaforycznych nazw strategii oraz określenie płaszczyzn funkcjonowania wymagało jednak wyjaśniającego aneksu. Został on sprecyzowany na podstawie prac Sushila (2001) oraz Osbert-Pociechy (2009) z własnymi zmianami. Znalazły się w nim zaproponowane strategie, które zdefiniowano w następujący sposób:

- Strategia Bambus - jej istotą jest zdolność do adaptacji, w tym także adaptacji przestrzennej. Odwołanie do właściwości bambusa ma wskazywać na korzyści wynikające

\footnotetext{
${ }^{1}$ Do badań wytypowano przedsiębiorstwa, które według PKD 2004 zaliczono do Sekcji D (Przetwórstwo przemysłowe) oraz w których liczba pracujących przekraczała 49 osób.
} 
z elastyczności działania, bowiem bambus jest w stanie przetrwać nawet bardzo silne wiatry, poprzez uginanie się, a następnie wracanie do pierwotnego kształtu. Pozostaje przy tym własny cel i kierunek działań.

- Strategia Kameleon - to strategia oparta na zdolności dopasowywania się do turbulentnego otoczenia. W świecie przyrody zmiana barw jest zjawiskiem dość częstym, ale ich powody są różne. Podobnie wśród przedsiębiorstw, gdyż zdolność dopasowywania się do otoczenia może wynikać z krótkookresowych, ratunkowych działań stabilizujących, z chęci uzyskania przewagi konkurencyjnej czy też z naśladownictwa, które nie musi prowadzić do wzrostu, ale zapewnia możliwość funkcjonowania.

- Strategia Gepard - odznacza się przede wszystkim szybkością reakcji na zmiany. To owa szybkość, wynikająca ze zwinności, zapewnia atut przy polowaniu na inne zwierzęta. Szybkość reakcji może wynikać z umiejętności czytania sygnałów pochodzących z otoczenia lub zachowań innych przedsiębiorstw, poprawności interpretacji sygnałów, szybkości procesu decyzyjnego i wdrożeniowego, wreszcie z szybkości oceny podjętych działań. Wszystkie te kroki nie są jednak prostą sumą jednostek czasu, ale tworzą nową jakość, która zapewnia przewagę nad innymi.

- Strategia Gitara - charakteryzuje ją pojęcie równowagi, odnoszącej się nie tylko do napięcia strun, ale i do ogólnie przyjętego sposobu gry, działania. Natomiast równowaga w przedsiębiorstwie to przede wszystkim utrzymanie, kontrolowanie, ewentualnie wspieranie (np. inwestycyjnie) wszystkich elementów łańcucha produkcji i zatrudnienia oraz więzi przestrzenno-produkcyjnych. Ponadto równowaga w przedsiębiorstwie to dbałość o zrównoważony rozwój.

- Strategia Jaskółka - jest utożsamiana z wolnym, niezależnym myśleniem i działaniem, które prowadzi do bardziej efektywnego funkcjonowania przedsiębiorstwa. Wolność pobudza innowacyjność i kreatywność. Warto jednak podkreślić, że wolność nie oznacza samowoli czy anarchii, lecz zdyscyplinowanie w dążeniu do wyznaczonego celu.

- Strategia Dziecko - odnosi się do konsekwencji dorastania i uzyskiwania rosnącej autonomii dziecka. Przyzwolenie na autonomię wiąże się więc z możliwością powstawania i rozwoju nowych przedsiębiorstw, często poprzez ograniczanie szeroko pojętych zależności nowych jednostek od podmiotu macierzystego.

- Strategia Wnuczek - obrazuje podejście dziadków do wychowania, którzy mają naturalną tendencję do ograniczania rygorów i kontroli. Wobec przedsiębiorstw można tutaj mówić o liberalizacji powiązań z innymi podmiotami gospodarczymi, w tym z przedsiębiorstwami podległymi. Według tej strategii związki kooperacyjne mogą przybierać bardzo swobodne formy i często zadaniowy charakter.

- Strategia Matka - istotne znaczenie odgrywa w niej poświęcenie w działaniu. Jest to możliwe przy jasno sprecyzowanym, choć bardzo emocjonalnym celu, jakim jest wychowanie dziecka. To z tego założenia wynika konsekwencja i odpowiedzialność, bez których przedsiębiorstwo, a raczej jego pracownicy nie osiagną sukcesu rynkowego.

- Strategia Niebo, która symbolizuje - podobnie jak strategia Jaskółka - wolność, lecz w tym przypadku wolność należy bardziej kojarzyć z otwartością. Otwartością na otoczenie, na inne przedsiębiorstwa, na ludzi w organizacji itp. Otwartość to także chęć i umiejętność obserwacji otoczenia.

Wobec wymienionych powyżej strategii można wysnuć wątpliwości co do ich zupełności i komplementarności, trafności i precyzyjności, niemniej - jak pokazują wyniki badań - ich użycie przyniosło szereg interesujących spostrzeżeń. 
Należy dodać, że każda ze strategii była rozpatrywana rozłącznie w odniesieniu do trzech płaszczyzn funkcjonowania przedsiębiorstwa: zasobów pracy, produkcji i decyzji lokalizacyjnych. Podobnie jak w przypadku strategii można mieć pewne wątpliwości zwłaszcza co do zupełności wybranych płaszczyzn, bowiem funkcjonowanie przedsiębiorstwa można i należy rozpatrywać w szerszym wymiarze, np. celów i funkcji, zasobów, technologii, a może przede wszystkim nadrzędnych wartości organizacji. Uznano jednak, że z punktu widzenia wymiaru przestrzennego omawianych zagadnień zaproponowane płaszczyzny będa wystarczająco reprezentatywne, a ich weryfikacja możliwie prosta.

Konieczne wydaje się jednak uściślenie owych płaszczyzn, w celu lepszego zrozumienia ich treści i motywów wyboru strategii przez przedsiębiorstwa.

- Płaszczyzna określona jako Ludzie dotyczy przede wszystkim strategii zatrudnienia i wpisanej w nią zasady kształcenia ustawicznego, w dalszej kolejności postaw pracowników i samego myślenia o pracy, natomiast w znacznie mniejszym stopniu zarządzania personelem i organizacji pracy.

- Płaszczyzna Produkcja odnosi się do kwestii profilu produkcji jako głównego rodzaju działalności oraz wielkości produkcji. Nie bez znaczenia są przy tym powiązania produkcyjne pasywne (zaopatrzenie) i aktywne przedsiębiorstwa (rynek zbytu).

- Płaszczyzna Lokalizacja to rozważania dotyczące konkretnego, faktycznego miejsca działalności produkcyjnej oraz ewentualnych nowych miejsc lokalizacji wynikających albo z procesu relokacji, albo z realizacji jednej ze strategii wzrostowej, np. integracji poziomej.

Zaproponowane strategie adaptacji i płaszczyzny funkcjonowania przedsiębiorstw stały się podstawą dla wcześniej omówionych badań ankietowych. Na ich podstawie wysunięto kilka kluczowych wniosków.

Wniosek pierwszy. Wśród badanych przedsiębiorstw przemysłowych województwa pomorskiego istnieje duże zróżnicowanie wybieranych strategii w każdej z badanych płaszczyzn. Każde przedsiębiorstwo szuka w zasadzie własnych rozwiązań tak w zatrudnieniu, produkcji, jak i korzyściach wynikających z konkretnej lokalizacji (tab. 2).

Tab. 2. Najczęściej wybierane strategie adaptacji według przyjętych płaszczyzn funkcjonowania przedsiębiorstwa wśród badanych przedsiębiorstw przemysłowych województwa pomorskiego w latach 2007-2008

\begin{tabular}{|l|c|l|c|l|c|}
\hline \multicolumn{5}{|c|}{ Płaszczyzny funkcjonowania przedsiębiorstwa } \\
\hline Strategia & $\begin{array}{c}\text { Wielkość wskazań } \\
\text { strategii w badanych } \\
\text { przedsiębiorstwach } \\
\text { ogółem } \\
(\%)\end{array}$ & Strategia & $\begin{array}{c}\text { Wielkość wskazań } \\
\text { strategii w badanych } \\
\text { przedsiębiorstwach } \\
\text { ogółem } \\
(\%)\end{array}$ & $\begin{array}{c}\text { Strategia } \\
\text { Produkcja }\end{array}$ & $\begin{array}{c}\text { Wielkość wskazań } \\
\text { strategii w badanych } \\
\text { przedsiębiorstwach } \\
\text { ogółem } \\
(\%)\end{array}$ \\
\hline Gitara & 58,9 & Gepard & 76,7 & Bambus & 63,0 \\
\hline Matka & 36,9 & Kameleon & 68,5 & Niebo & 61,6 \\
\hline Niebo & 27,4 & Jaskółka & 54,8 & Dziecko & 26,0 \\
\hline
\end{tabular}

Źródło: Opracowanie na podstawie własnych badań terenowych zrealizowanych w 2009 r. 
W płaszczyźnie Ludzie zdecydowanie dominuje strategia Gitara, która potwierdza nastroje w przedsiębiorstwach. Jak bowiem wynika z badań, w latach 2007-2008 większość przedsiębiorstw przyjęła za priorytet utrzymanie dotychczasowego stanu zatrudnienia bez wyraźnych zmian ilościowych. Tym samym większość działań w przedsiębiorstwach koncentrowała się na optymalizacji dotychczasowych stanowisk pracy, np. poprzez ich dozbrojenie techniczne, lub na podnoszeniu kwalifikacji i umiejętności pracowników, co miało wpłynąć na wzrost wydajności pracy. W otrzymanych ankietach strategia Gitara często współwystępuje ze strategią Matka, która potwierdza fakt przemyślanych, zamierzonych i konsekwentnie realizowanych działań w sferze zatrudnienia. Można zatem stwierdzić, że w latach 2007-2008 przedsiębiorstwa przemysłowe województwa pomorskiego przyjmowały najczęściej takie strategie, które mimo pierwszych oznak ogólnoświatowego kryzysu gospodarczego nie prowadziły do gwałtownych redukcji zatrudnienia, co może świadczyć albo o silnej pozycji konkurencyjnej przedsiębiorstw, tak jak np. w przetwórstwie rybnym, albo o dużych niewykorzystywanych rezerwach w zatrudnieniu (np. w przemyśle drzewnym). Możliwa jest jednak i taka interpretacja, że przyjmowane strategie wynikają ze słabo przygotowanej analizy strategicznej, a przez to funkcjonowania tylko na podstawie decyzji na poziomie operacyjnym (tab. 3 ).

Tab. 3. Liczba pracujących w przemyśle w województwie pomorskim w latach 2007-2008 (w tys.)

\begin{tabular}{|l|c|c|c|}
\hline \multicolumn{1}{|c|}{ Wyszczególnienie } & 2007 & 2008 & $2007=100$ \\
\hline Przemysł & 154,9 & 153,9 & 99,35 \\
\hline w tym przetwórstwo przemysłowe & 137,4 & 137,5 & 100,07 \\
\hline
\end{tabular}

Źródło: Pracujący w województwie pomorskim w 2008 r., WUS, Gdańsk 2009

Wyniki badań wskazują, że w płaszczyźnie Produkcja najczęściej wskazywaną strategią (znacznie częściej aniżeli strategia Gitara w płaszczyźnie Ludzie) była strategia Gepard. Może to świadczyć nie tylko o tym, iż szybkość reakcji na zachodzące zmiany otoczenia i zachowań innych uczestników gry rynkowej decyduje obecnie o bycie lub niebycie podmiotu gospodarczego, ale również o znacznie węższym, aniżeli w płaszczyźnie Ludzie, zakresie przyjmowanych działań. Trudno jednak jednoznacznie wskazać, co mogło być tego przyczyna, bowiem wpływ na wybór strategii Gepard może wynikać z jednej strony z bardzo dobrze funkcjonującego marketingu przedsiębiorstwa, a z drugiej - z tzw. naśladownictwa w produkcji. Tę alternatywę może potwierdzać również bardzo często wybierana strategia Kameleon, która może, ale nie musi zapewniać wyraźnego wzrostu produkcji, dając przy tym względną gwarancję na dalsze funkcjonowanie. Docenić należy także trzecią z najczęściej wybieranych strategii w omawianej płaszczyźnie, jaką jest strategia Jaskółka. Być może to realizacja tej strategii na podstawie innowacyjności produkcji i kreatywności handlowej, np. w przemyśle naftowym, spowodowała znaczący wzrost produkcji sprzedanej w przemyśle województwa pomorskiego w latach 2007-2008 (tab. 4). 
Tab. 4. Produkcja sprzedana w przemyśle w województwie pomorskim w latach 2007-2008 (w mln zł)

\begin{tabular}{|c|c|c|c|}
\hline \multicolumn{1}{|c|}{ Wyszczególnienie } & 2007 & 2008 & $2007=100$ \\
\hline Przemysł & 43539,7 & 54007,0 & 124,04 \\
\hline w tym przetwórstwo przemysłowe & 39665,5 & 48856,6 & 123,20 \\
\hline
\end{tabular}

Źródło: Biuletyn statystyczny województwa pomorskiego, I kwartał 2009, WUS, Gdańsk 2009

W trzeciej z uwzględnionych w badaniach płaszczyzn - Lokalizacja - obserwuje się znaczący udział we wskazaniach strategii Bambus, która sugeruje kurczenie się terenów przemysłowych w części powiatów województwa, lecz - jak wynika z uzyskanych wypowiedzi - nie musi ono być ostateczne i definitywne.

Bardzo mocno deklarowana jest też strategia Niebo, co ma oznaczać otwartość przedsiębiorstw na przesunięcia przestrzenne, w tym relokację lub ekspansję terytorialną. Obie dominujące strategie pozornie się wykluczają, lecz należy zwrócić uwagę, że rezygnacja z działalności w jednym miejscu nie musi oznaczać całkowitej likwidacji przedsiębiorstwa, lecz proces relokacji. Natomiast otwartość przedsiębiorstw na przesunięcia przestrzenne nie musi wynikać z mocnej pozycji rynkowej, lecz z próby poszukiwania tańszej lokalizacji. Słuszne wydaje się więc stwierdzenie bazujące na obu omawianych strategiach, że w województwie pomorskim następują zmiany struktury przestrzennej przemysłu wywołane m.in. osłabieniem roli miast jako ważnych miejsc skupiających przemysłowy potencjał produkcyjny, przeniesieniem działalności produkcyjnej w strefy podmiejskie czy też funkcjonowaniem specjalnych stref ekonomicznych z licznymi podstrefami skupiającymi przemysłowy potencjał produkcyjny (Czapliński 2007).

Wniosek drugi. Przyjmowane przez przedsiębiorstwo strategie adaptacji dotyczące określonej płaszczyzny ulegają często zmianie lub przynajmniej modyfikacji. Przy czym najczęstsze zmiany (niezależnie od ich kierunku) następują w płaszczyźnie produkcji, gdzie liczba zmian (mierzona w badaniach liczbą zmian lub modyfikacji strategii adaptacyjnych w ciagu roku) sięgała w dwóch skrajnych przypadkach sześciu (ryc. 1).

Warto przy tym podkreślić, że charakter zmian produkcyjnych był związany z lepszym dopasowaniem jakościowym do wymogów rynkowych, w tym wymogów rynku europejskiego, nie zaś z samą wielkością produkcji. Należy także zauważyć, że w zasadzie co drugie badane przedsiębiorstwo wprowadziło w ciągu roku przynajmniej jedną modyfikację przyjętej uprzednio strategii w zakresie produkcji. Zmiany same w sobie mogą być oceniane jako objaw pozytywny, który świadczy o umiejętności oceny zachodzących procesów rynkowych i możliwie szybkim dostosowywaniu się do nich. Wydaje się jednak, że zbyt duża liczba zmian oznacza słabe rozpoznanie rynku, otoczenia i przedsiębiorstw konkurencyjnych lub wynika z ograniczonych zasobów, których niedobór determinuje konkretne zachowanie.

Dużo większa zachowawczość występuje w płaszczyźnie Ludzie, gdzie niespełna $60 \%$ badanych przedsiębiorstw nie deklaruje zmiany strategii, co umacnia wnioski płynące z wcześniejszych ustaleń autora, a jednocześnie wskazuje na zupełnie inną specyfikę zarządzania produkcją i personelem. 


\section{Produkcja}

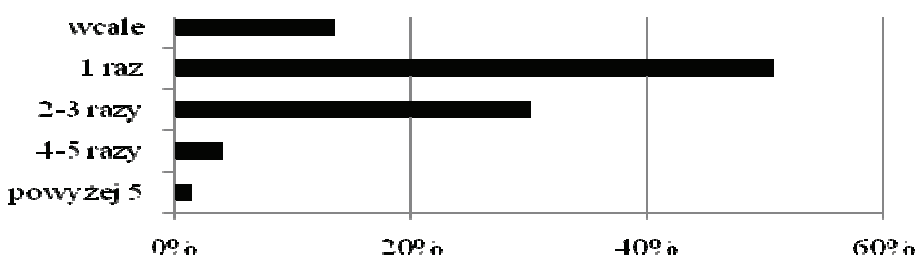

Ludzie

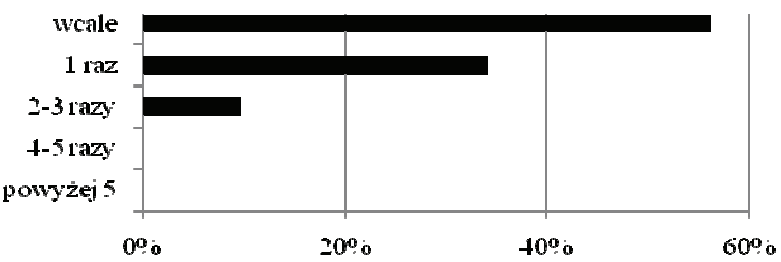

Lokalizacja

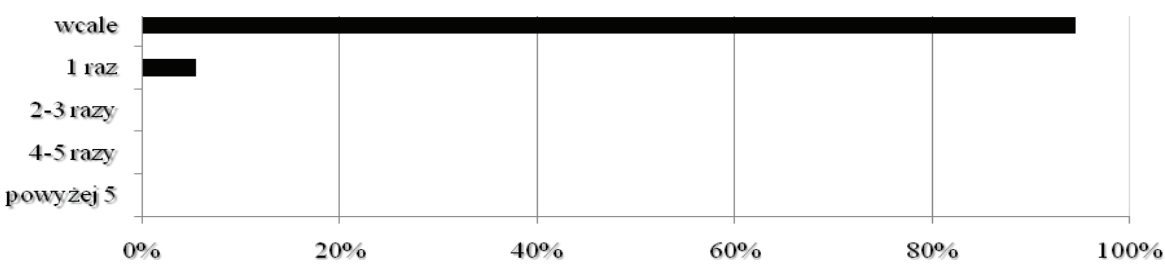

Ryc. 1. Liczba zmian lub modyfikacji strategii adaptacyjnych realizowanych w ciągu roku w badanych przedsiębiorstwach województwa pomorskiego według badanych płaszczyzn funkcjonowania

Źródło: Opracowanie własne na podstawie badań terenowych

Wydaje się, że w płaszczyźnie Lokalizacja, w latach 2007-2008 nie zachodziły znaczące zmiany, niemniej jednak na skutek realizacji nowych strategii 4 przedsiębiorstwa przemysłowe (5,5\% ogółu badanych) zmieniły swoją lokalizację. Na tym etapie badań istnieją jednak wątpliwości co do oceny skali tego zjawiska. Ponadto należy wziąć pod uwagę fakt, że analiza dotyczyła bardzo wąskiego przekroju czasowego, który nie oddaje w pełni przyczyn i rozmiaru przesunięć przestrzennych w dłuższym horyzoncie czasowym.

Wniosek trzeci. Strategie adaptacyjne realizowane przez badane przedsiębiorstwa przemysłowe województwa pomorskiego zależą od ich dostępności przestrzennej, szczególnie zaś położenia względem głównych korytarzy transportowych. Potwierdza to wyraźna zależność przestrzenna pomiędzy koncentracją działalności przemysłowej zobrazowaną wskaźnikiem koncentracji przestrzennej przemysłu (liczba pracujących w przemyśle na $1 \mathrm{~km}^{2}$ ) dla miast i gmin województwa oraz przebiegiem głównych korytarzy transportowych (ryc. 2). 


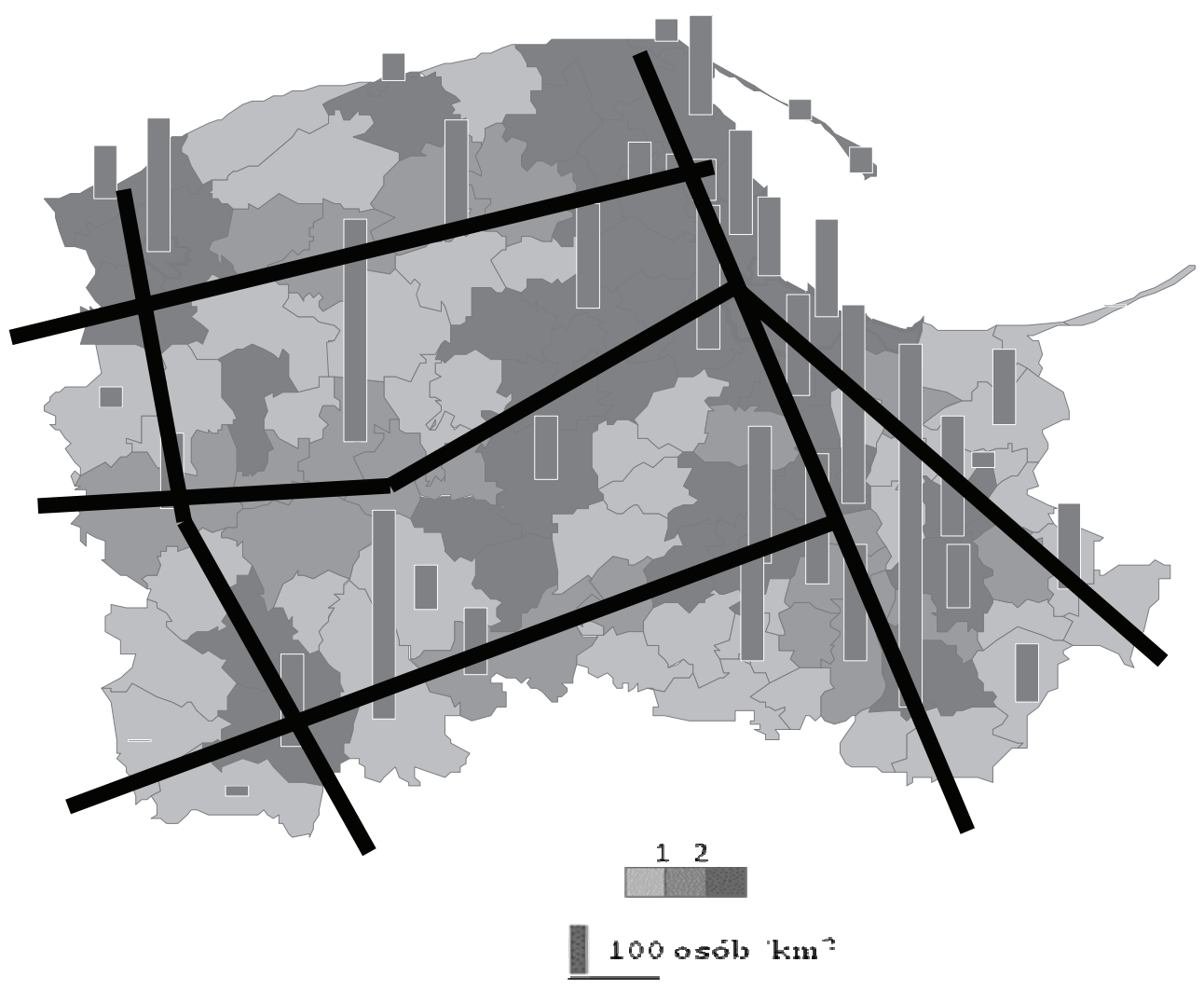

osie korytarzy transportowych województwa pomorskiego

Ryc. 2. Koncentracja przestrzenna przemysłu w województwie pomorskim w $2008 \mathrm{r}$. na tle głównych korytarzy transportowych

Źródło: Opracowanie własne na podstawie danych Urzędu Marszałkowskiego Województwa Pomorskiego - Plan Zagospodarowania Przestrzennego Województwa Pomorskiego, Gdańsk 2003

$\mathrm{Na}$ podstawie przebiegu głównych korytarzy transportowych w województwie pomorskim podzielono jednostki administracyjne na te, które leżą w korytarzach lub w ich bezpośrednim sąsiedztwie oraz te, które położone są poza nimi. Zaproponowany podział wynika z zaobserwowanej prawidłowości. Otóż przedsiębiorstwa położone w jednostkach administracyjnych, przez które nie przebiegają główne korytarze komunikacyjne, przyjmują nie tylko inne strategie adaptacyjne, lecz również inna jest istotność badanych płaszczyzn funkcjonowania aniżeli w przedsiębiorstwach zlokalizowanych wzdłuż korytarzy (tab. 5).

Wśród przedsiębiorstw zlokalizowanych w korytarzach komunikacyjnych priorytetowa okazała się płaszczyzna Ludzie, co można wiązać z tezą A. Zorskiej (2009), że: „obecnie ma miejsce poszukiwanie wiedzy i umiejętności w otoczeniu, czemu sprzyja rozwój korytarzy transferu zasobów". Wskazane w tej płaszczyźnie dominujące strategie (Jaskótka i Niebo) związane z otwartością, kreatywnością i otwartością na otoczenie potwierdzają podaną tezę. Pozostałe dwie płaszczyzny dla tej grupy jednostek mają raczej charakter zachowawczy. 
Tab. 5. Przyjmowane strategie adaptacji przez badane przedsiębiorstwa przemysłowe województwa pomorskiego na tle przebiegu korytarzy komunikacyjnych w $2008 \mathrm{r}$.

\begin{tabular}{|c|c|c|c|c|}
\hline \multirow{2}{*}{$\begin{array}{c}\text { Istotność } \\
\text { płaszczyzn } \\
\text { funkcjonowania } \\
\text { przedsiębiorstw }\end{array}$} & \multicolumn{4}{|c|}{ Jednostki administracyjne (miasta i gminy) } \\
\cline { 2 - 5 } & w korytarzach komunikacyjnych & poza korytarzami komunikacyjnymi \\
\hline 1. & Ludzie & $\begin{array}{c}\text { Jaskółka } \\
\text { Niebo }\end{array}$ & Lokalizacja & $\begin{array}{c}\text { Jaskółka } \\
\text { Wnuczek }\end{array}$ \\
\hline 2. & Produkcja & $\begin{array}{c}\text { Bambus } \\
\text { Kameleon }\end{array}$ & Ludzie & $\begin{array}{c}\text { Matka } \\
\text { Gitara }\end{array}$ \\
\hline 3. & Lokalizacja & $\begin{array}{c}\text { Gitara } \\
\text { Niebo }\end{array}$ & Produkcja & $\begin{array}{c}\text { Gepard } \\
\text { Kameleon }\end{array}$ \\
\hline
\end{tabular}

Źródło: Opracowanie na podstawie własnych badań terenowych zrealizowanych w 2009 r.

Odmienne strategie adaptacji przyjmująjednostki produkcyjne poza korytarzami. W tym przypadku znaczna aktywność przedsiębiorstw przejawia się w płaszczyźnie Lokalizacja, co najczęściej wynika z prób uatrakcyjnienia własnego położenia (np. poprzez inwestycje w drogi dojazdowe, atrakcyjne powiązania przestrzenno-organizacyjne) lub w poszukiwanie nowych, czasem dodatkowych miejsc lokalizacji nie zawsze związanych bezpośrednio z procesem produkcyjnym, lecz częściej z działalnością handlową.

Podobieństwo pozycji płaszczyzny produkcyjnej w obu grupach należy tłumaczyć przeniesieniem akcentu decyzji lokalizacyjnej z pytania gdzie na pytanie dla kogo produkować, bowiem znaczenia nabiera obecnie wielkość i dostępność do rynku. Istnieją jednak znaczne różnice grup w preferowanych strategiach, co należy wiązać m.in. z dyfuzją innowacji, której sprzyjają korytarze komunikacyjne oraz bardziej agresywną działalnością marketingową przedsiębiorstw zlokalizowanych poza korytarzami.

Wniosek czwarty. Strategie adaptacji przedsiębiorstw przemysłowych w województwie pomorskim mają uwarunkowania kulturowe, które determinują obraz przestrzenny przemysłu. Potwierdza to konfrontacja koncentracji przestrzennej przemysłu z granicami etnoregionu kaszubskiego ${ }^{2}$. Ta wyraźna korelacja przestrzenna w dużej mierze odnosi się do płaszczyzny Produkcja, w której to dominują strategie Kameleon i Gepard. Wydaje się bowiem, że przedsiębiorstwa na Kaszubach szybciej przystosowują się do nowych uwarunkowań rynkowych, stosując działania wyprzedzające, jednak polega to na naśladownictwie, które zapewnia odpowiednio duży zapas czasowy wynikający z pominięcia procesów badawczo-rozwojowych nowych produktów. Jest to też impuls do powstawania nowych jednostek produkcyjnych, w oparciu o silne lokalne powiązania społeczno-gospodarcze. Natomiast wpływ na pozostałe dwie płaszczyzny, w których obserwuje się bardzo niską dynamikę zmian, ma etniczność kaszubska związana z przywiązaniem do terytorium i często rodzinnymi więziami pracujących. Stąd przyjmowane w tych płaszczyznach dominujące strategie to Gitara, Dziecko oraz Jaskótka, które podkreślają równowagę, odpowiedzialność, konsekwencję, niezależność i kreatywność w funkcjonowaniu kaszubskich przedsiębiorstw. Przedsiębiorstwa położone poza Kaszubszczyzną wykazują znacznie większy indywidualizm przy wyborze strategii w poszczególnych płaszczyznach funkcjonowania, dlatego ich uogólnienie nie wydaje się zasadne (ryc. 3).

\footnotetext{
2 Granice etnoregionu zostały wyznaczone na podstawie pracy: J. Mordawski, Geografia współczesnych Kaszub, Wyd. Rożak, Gdańsk 1999.
} 


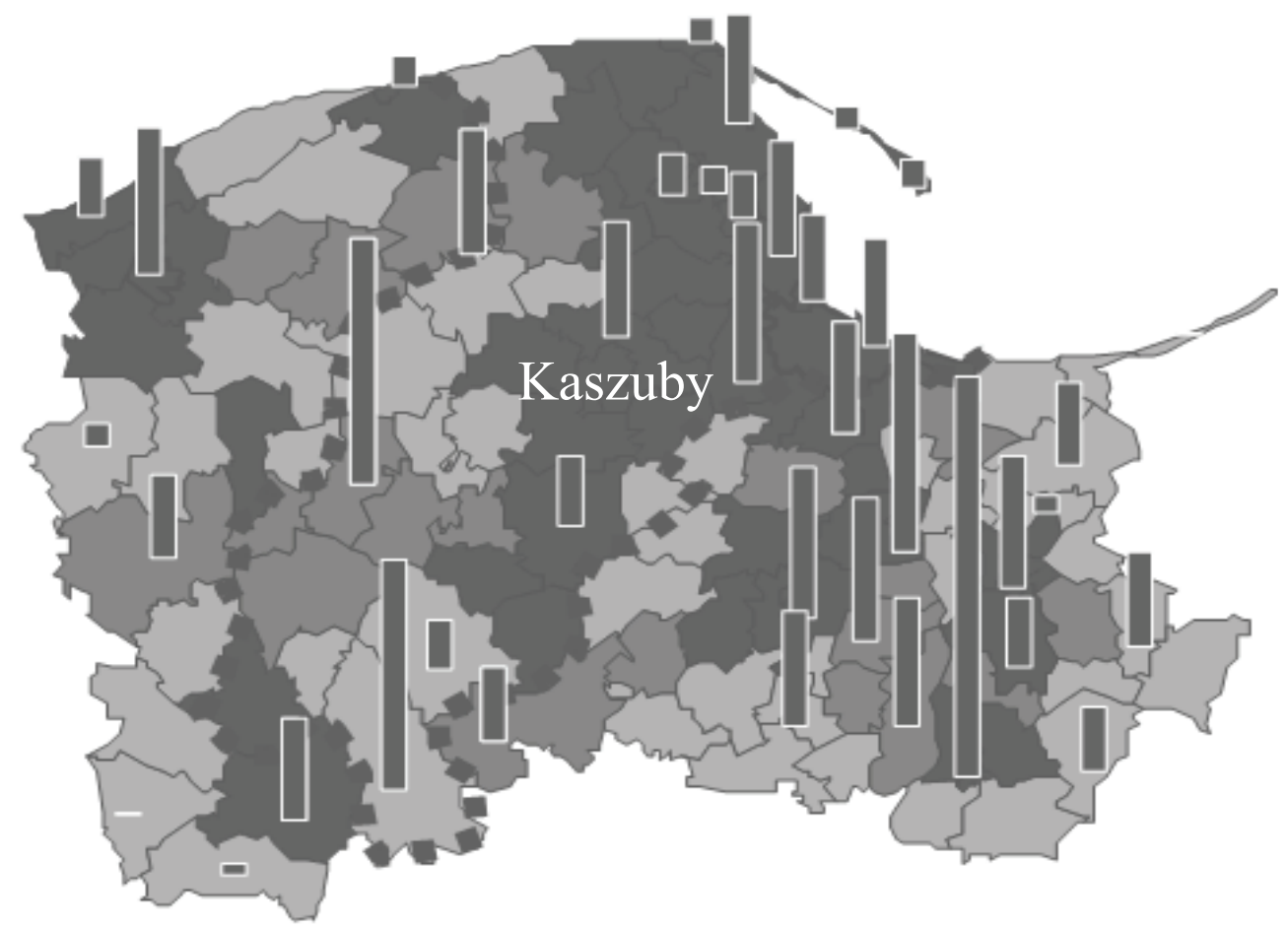

Ryc. 3. Koncentracja przestrzenna przemysłu województwa pomorskiego na tle etnoregionu kaszubskiego w $2008 \mathrm{r}$.

Źródło: Opracowanie własne na podstawie pracy: J. Mordawski, Geografia współczesnych Kaszub, Wyd. Rożak, Gdańsk 1999

Oczywiste jest, że zarysowane powyżej problemy nie wyczerpują listy wniosków wynikających z przeprowadzonych badań, ponieważ nie odnoszą się one np. do roli instytucji otoczenia biznesu w wyborze strategii czy wpływu sytuacji makroekonomicznej kraju na zachowania przedsiębiorstw. Wprowadzenie jednak większej liczby zależności (które będą przedmiotem odrębnych analiz) być może spowodowałoby rozmycie głównego celu badań.

W świetle zaprezentowanych wniosków należy poczynić pewną refleksję ogólną, dotyczącą tak samej metodologii badań, jak i wnioskowania. Otóż wydaje się, że dla pełniejszej oceny formy, czy też sposobu zachowania się przedsiębiorstwa niezbędne jest jej rozpatrywanie przy znacznie większej liczbie płaszczyzn opisujących organizację, aniżeli wyżej wymienione. Wydaje się, że warto pogłębić badania o takie wymiary jak: cele, funkcje, technologia, rynek itp. Być może po zbadaniu większej liczby płaszczyzn ich charakterystyki byłyby gotowymi odpowiedziami dla pozostałych. Ponadto strategie przedsiębiorstw na poziomie decyzyjnym, a tym bardziej strategicznym nie muszą być powiązane z konkretnym fizycznym miejscem. Współcześnie mamy przecież do czynienia z procesami globalizacji i integracji gospodarki, z ich wszelkimi konsekwencjami. Ponadto wydaje się, że istnieje potrzeba badań panelowych dotyczących strategii przedsiębiorstw i ich elastyczności, ponieważ zarówno sam mechanizm, jak i ocena zmian może nastąpić w dłuższej perspektywie czasowej. Na uwagę zasługuje również fakt, że uzyskane w toku badań odpowiedzi mogą 
mieć niekiedy charakter subiektywny, co wynika m.in. z samooceny respondentów. Potrzeba więc korekty wyników badań opartych na twardych danych. Wreszcie można mieć pewne wątpliwości, czy liczba przyjętych w badaniach strategii jest skończona. Wydaje się, że zaprezentowane strategie zakładają raczej działania aktywne, a przynajmniej pozytywne. Nie wyczerpuje to jednak listy działań. Ostatnia wątpliwość dotyczy reprezentatywności próby w kontekście ilościowym oraz kwestii jej doboru. Wydaje się bowiem, że obserwowane procesy w przestrzeni przemysłowej województwa pomorskiego muszą być poparte większą liczbą przykładów.

Reasumując i mając na uwadze powyższe uwagi należy stwierdzić, że wpływ strategii działania przedsiębiorstw przemysłowych, silnie determinowanych umiejscowieniem, na strukturę przestrzenną przemysłu województwa pomorskiego jest ewidentny. Badania ankietowe przeprowadzone wśród przedsiębiorstw przemysłowych województwa pomorskiego skłaniają do ogólnego wniosku, iż strategie przedsiębiorstw w badanych wymiarach, niezależnie od ich charakteru, mają wpływ na strukturę przestrzenną przemysłu województwa pomorskiego, jednakże ich skala, zakres i kierunek nie zostały jeszcze w pełni zidentyfikowane i będą przedmiotem dalszych badań.

\section{Literatura}

Czapliński P., 2007, Kształtowanie się struktur przemysłowych województwa pomorskiego, [w:] J. Lach, M. Borowiec, T. Rachwał (red.), Procesy transformacji społeczno-ekonomicznych i przyrodniczych struktur przestrzennych, Wyd. Nauk. AP, Kraków

Krumme G., 1969, Notes on locational adjustment patterns in industrial geography, Geografiska Annaler, Vol. 51, No. 1, Series B, Human Geography, Stockholm

Krupski R., 2005, Elastyczność polskich przedsiębiorstw, Przegląd Organizacji, nr 11

Osbert-Pociecha G., 2009, Elastyczność organizacji - „tańczenie” w turbulentnym otoczeniu, www. wiedzainfo.pl/wyklady/1297/ elastycznosc_organizacji_tanczenie_w_turbulentnym_otoczeniu. html. [20.11.2009]

Stryjakiewicz T., 1999, Adaptacja przestrzenna przemystu w Polsce $w$ warunkach transformacji, Wyd. Nauk. UAM, Poznań

Sushil, 2001, Flexibility metaphors, Systems Research and Behavioral Science, Vol. 18, Issue 6, s. $569-575$

Walker D.F., 1975, A behavioural approach to industrial location, [w:] L. Collins, D.F. Walker (red.), Locational dynamics of manufacturing activity, London

Volberda, H.W., 1998, Building the flexible firm - how to remain competitive, Oxford University Press, Oxford

Ziąber P., 2003, Transformacje systemów gospodarczych, referat wygłoszony na konferencji „Transformacja - Integracja - Globalizacja”, która odbyła się w dniach 15-16 maja 2003 r. w Krakowie, http://janek.ae.krakow.pl/ ekte/strona/aktual.html [26.01.2010]

Zorska A., 2009, Ku globalizacji działalności innowacyjnej korporacji transnarodowych, [w:] O. Dębicka, A. Oniszczuk-Jarząbek, T. Gutowski, J. Winiarski (red.), Przedsiębiorstwo w otoczeniu globalnym, Wyd. UG, Gdańsk 


\section{Spatial industrial transformation processes in the Pomorskie voivodship}

The article attempts to assess the impact of the strategy for industrial companies on the spatial structure of Pomeranian industry. Strategies are analyzed on the level of labour resources, production and location decisions. In order to avoid formal difficulties and testing of new methodological solutions, the selected strategies were characterized on the basis of the metaphorical approach. Surveys conducted among industrial companies of the Pomorskie voivodship, using the above-mentioned method, tend to the general conclusion that the forms of behaviour in the tested businesses regardless of their volatility, have an influence on the spatial structure of Pomeranian industry, however its scale, scope and direction have not yet been fully identified.

\section{Dr Paweł Czapliński}

Akademia Pomorska w Słupsku

e-mail: somma@go2.pl 